\title{
Case study on woody plant introduction into white oasis soil under limited watering in Inner Mongolia, China
}

\section{OBAYASHI, Sunao ${ }^{* 11} \cdot$ AZAMI, Kazuhiro ${ }^{1)} \cdot \mathbf{L U}$, Zhicheng ${ }^{3)} \cdot$ AN, Kongjian ${ }^{3)} \cdot \mathrm{HE}$, Yongming ${ }^{4)} \cdot$ SAITOU, Hiroshi ${ }^{1)} \cdot$ LIU, Ying ${ }^{2)}$ and YAMADERA, Yoshinari ${ }^{5)}$}

\author{
1) OYO Corporation, Global Environment Business Division \\ 2) OYO Corporation, Research and Development Center \\ 3) Tsinghua University, Academy of Arts \& Design \\ 4) Xilingol League Yonglian Trade Co., Ltd \\ 5) Professor, Shinshu University, Faculty of Agriculture (at present: Independent Scholar)
}

\begin{abstract}
White oasis soil, which is widely distributed in the Inner Mongolia Autonomous Region of China, prevents the growth of root systems by forming an impermeable layer of hard calcium carbonate, and therefore is not suitable for plant growth. Consequently, it is difficult to restore the ecology once the land is devastated. Efforts to restore or reproduce the ecology in this region by continuously planting and watering large seedlings have had little success. Therefore, this study examined how to introduce woody plants into white oasis soil under limited watering conditions. For this study, nursery block seedlings of eight tree species were planted to compare their compatibility with white oasis soil. As a result, regarding the compatibility with white oasis soil, the survival rate one year and two months after planting was highest at 98\% for Ulmus pumila L., 85\% for Syringa oblata Lindl., 52\% for Prunus persica (L.) Batsch, and $40 \%$ or less for the other five tree species. The result of the above test suggests the possibility of introducing woody plants into white oasis soil under limited watering conditions by planting U. pumila, S. oblata, P. persica and other tree species highly compatible with white oasis soil.
\end{abstract}

Key words: White oasis soil, Planting, Limited watering, Nursery block seedling

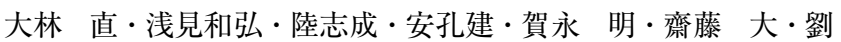
瑛・山寺喜成 : 中国内モンゴル自治区の白干土における低潅水条 件下での樹木導入試験

摘要：中国内モンゴル自治区に広く分布する白干土は，固い炭酸 カルシウムの不透水層を形成し根系の伸長を阻害するなど, 植物 の生育には不向きである。このため, 土地が荒廃化しても生態環 境の修復は困難となっている。現地では, 大苗を植栽し多量の潅 水を継続的に行っているが，生態環境の修復再生はほとんど進ん でいない。そこで, 本報告では, 白干土において低潅水条件下で
保育ブロック苗を用いて樹木を導入する手法を検討した。白干土 への適合性の高い樹種は, 施工 1 年 2 か月後の活着率をみると二 レ (Ulmus pumila L.) が最も高い $97.8 \%$ を示し, ライラック (Syringa oblata Lindl.) が $84.4 \%$, モモ (Prunus persica (L.) Batsch) が $52.3 \%$, 他の 5 種類の樹木の活着率は $40 \%$ 以下だった。白干 土に適合性の高いU. pumila (ニレ), P. persica (モモ), S. oblata (ライラック）などの樹種を植栽することにより, 白干土におい て低潅水条件下で樹木を導入することが可能であるとの見通しを 得た。

キーワード : 白干土, 樹木導入, 低潅水, 保育ブロック

\section{Introduction}

White oasis soil is a calcium alkaline soil, which is widely distributed in the Inner Mongolia Autonomous Region of the People's Republic of China. Calcium carbonate contained in the soil easily consolidates to form a hard impermeable layer (hereinafter referred to as "calcium carbonate accumulation layer" that inhibits the growth of root systems and consequently the growth of local plants (Araya et al., 2003). The Inner Mongolia Autonomous Region, which makes up $28 \%$ of the total desert area in China (Wu, 2009), is a main source of yellow sand. The occurrence of strong winds over $17 \mathrm{~m} \mathrm{~s}-1$ erodes the surface soil and accelerates the devastation of the land (Wang, 2010). Therefore, it is considered important to restore the vegetation by introducing woody plants while creating a suitable environment for this purpose by developing wind buffer zones such as windbreaks.

The Chinese government actively plants Pinus L. and 
Populus L. in the white oasis soil region for the restoration of ecology (Dongwuzhumuqinqi government website, 2004). However, since the conventionally used large seedlings have their taproots cut, they do not root deep in the ground and therefore can only absorb water from a narrow range. Consequently, they need abundant watering after being planted. In the area of our field survey, it was often observed that most of the seedlings had withered and died even after watering. In addition, in semiarid areas such as the Inner Mongolia Autonomous Region, too much watering can result in lower groundwater levels, salt damage (Qu, 2009), and further deterioration of the ecology.

This study examined how to introduce woody plants into white oasis soil under limited watering conditions in accordance with the natural environment of such regions. It is considered that the reason why plant growth is restricted under white oasis soil is mainly because the roots of the plants cannot grow sufficiently due to the poor air permeability of the calcium carbonate accumulation layer, high soil hardness, and other physical properties of the soil. We examined what tree species which can establish in this area using nursery block seedling with success examples by little watering. This study compared the compatibility of eight tree species with white oasis soil.

\section{Study area}

The test was conducted in Dongwuzhumuqinqi, Xilingol League, Inner Mongolia Autonomous Region, where white oasis soil is distributed. Dongwuzhumuqinqi is located at $45^{\circ} 29^{\prime} 54^{\prime \prime}$ north latitude and $116^{\circ} 58^{\prime} 22^{\prime \prime}$ east longitude in the northeastern area of Xilingol League, and belongs to the steppe climate region. The elevation is 800 to $1,500 \mathrm{~m}$ (Fig. 1). According to the website of the popular government of Dongwuzhumuqinqi (Dongwuzhumuqinqi government website, 2016), the annual highest temperature is $39.7^{\circ} \mathrm{C}$, annual lowest temperature is $-40.7^{\circ} \mathrm{C}$, annual average temperature is $1.6^{\circ} \mathrm{C}$, average temperature of the warmest month (July) is $21.0^{\circ} \mathrm{C}$, and average temperature of the cold-

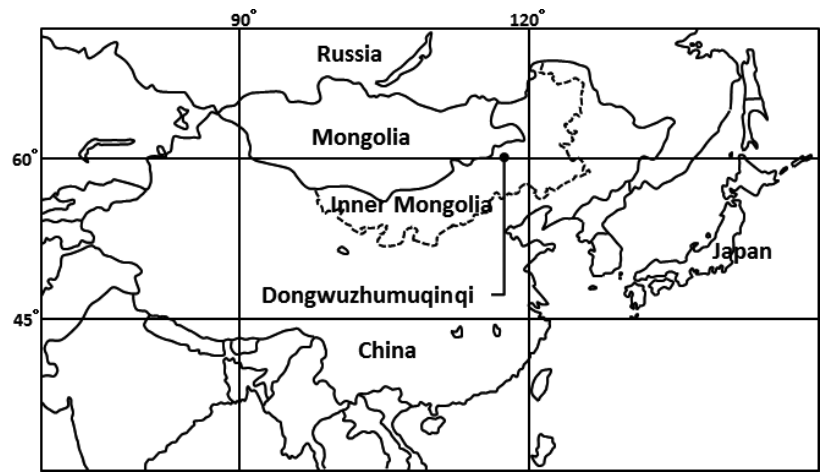

Fig. 1 Location of study area in Dongwuzhumuqinqi est month (January) is $-18.9^{\circ} \mathrm{C}$. The annual precipitation is around $300 \mathrm{~mm}, 70 \%$ of which occurs from June through August. The annual evaporation from soil is over $3,000 \mathrm{~mm}$, which is ten times the annual precipitation. The average wind speed is $3.6 \mathrm{~m} \mathrm{~s}-1$, and the maximum instantaneous wind speed, $34.0 \mathrm{~m} \mathrm{~s}-1$.

The test site was set at a flat land area of approx. $50 \times 75 \mathrm{~m}$ in Dongwuzhumuqinqi. Around the test site, Oryzoideae spreads, and goats, sheep, and cows graze, whereas inside the test site, Artemisia L. dominates. According to on-site hearing surveys, barley, field mustard, and potatoes were once cultivated in the test site, but the site has been left unused since 2012 due to decreased crop yields. It is considered that Artemisia L. increases instead of Oryzoideae in wastelands, which is not desirable for grazing.

Figure 2 shows the results of the soil profile investigation of the test site carried out as a preliminary survey in August 2013. The thickness of the surface soil is approx. $30 \mathrm{~cm}$, and the calcium carbonate accumulation layer is distributed with a thickness of approx. $80 \mathrm{~cm}$ between a depth of $30 \mathrm{~cm}$ and $80-120 \mathrm{~cm}$. Also, there is a sand and pebble layer under the calcium carbonate accumulation layer. The gas phase rate and coarse pore rate of the calcium carbonate accumulation layer are $27 \%$ and $5 \%$, respectively. The soil hardness measured with a Yamanaka soil hardness meter (Pocket type, Fujiwara Scientific, Tokyo, Japan) is $27 \pm 1.7 \mathrm{~mm}$, and the saturated hydraulic conductivity is $3.3 \times 10^{-7} \mathrm{~cm} \mathrm{~s}-1$. The moisture contained in white oasis soil was approx. $7 \%$ at a depth of $10 \mathrm{~cm}$, approx. $10 \%$ at $20 \mathrm{~cm}$, approx. $7 \%$ at $50 \mathrm{~cm}$, and approx. $7 \%$ at $70 \mathrm{~cm}$, when measured with a soil moisture meter (CS620, Campbell Scientific, Utah, USA). The root systems of the plants are easily found in the surface soil, but rarely found in the calcium carbonate accumulation layer.

Around the test site, seedlings are planted in combination with large-scale planting hole digging such as fish scale pitting (Fig. 3) in order to restore the ecology in the mountain areas, Pinus tabulaeformis Carr., Pinus sylvestris L. var. mongolica Litv., Prunus ansu Kom., Prunus davidiana (Carr.) Franch., and Syringa oblata Lindl. are planted in hilly areas, and Populus and Ulmus pumila L. are planted in flatlands.

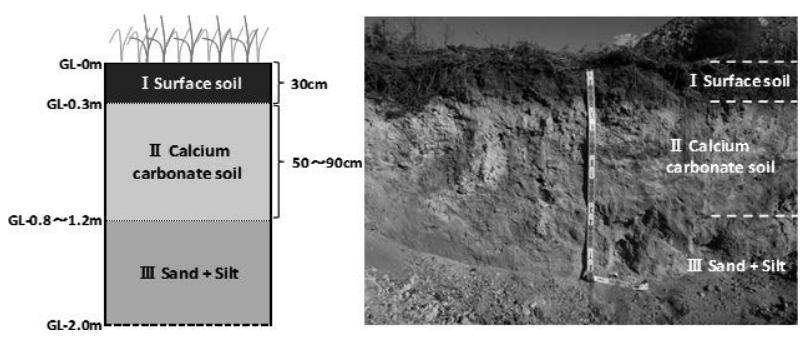

Fig. 2 Soil morphology of study area 


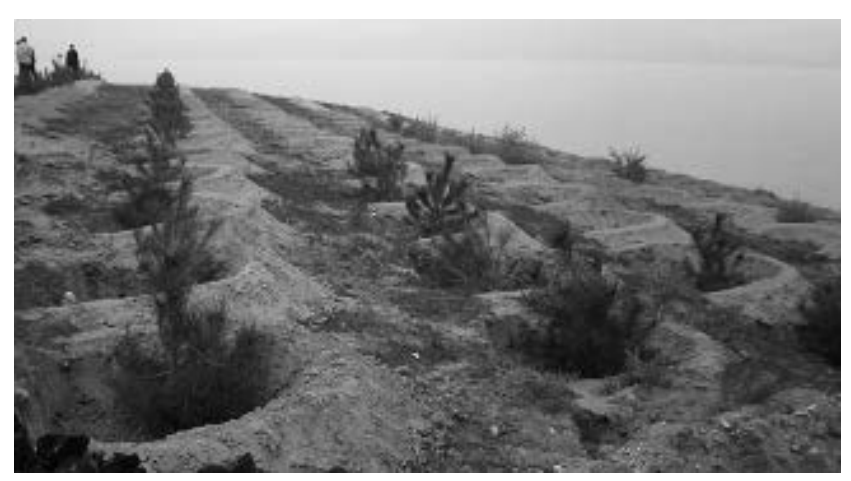

Fig. 3 Fish scale pit

However, abundant watering is required to grow seedlings. According to the local staff, a total of over $2,000 \mathrm{~L}$ of watering, more than 15 times per year is required for each street tree seedling.

\section{Methods}

\subsection{Preparation of Nursery Trees}

The conventionally used seedlings have their taproots cut at the raising stage, and therefore do not root deep in the ground regardless of the hardness of the soil. Consequently, they can only absorb water from a narrow range, and are therefore vulnerable to dryness and need abundant watering after being planted (Yamadera, 2014). This test used nursery blocks in which the taproots had not been cut at the raising stage and therefore were able to grow deep in the ground. Figure 4 shows the shape of the nursery block, the seedling raising stage (nursery block seedlings), and the planting outline.

The nursery block is a cylindrical soil block having a through hole and shallow grooves in the center (Chinese patent number: $\mathrm{CN} 125571 \mathrm{C}$ ), and the nursery block seedling is prepared by planting and growing the nursery block with its through hole filled with culture soil (Chinese patent number: CN101433167B). The nursery block protects the plant during the initial growing stage and guides the taproot deep in the ground along the through hole (Yamadera et al., 2002; Furubayashi et al., 2003; Nishikawa et al., 2004). It can also retain water and reduce withering of plants by decelerating the soil drying speed to slower than the growing speed of the root systems (Yamadera, 2010). Nursery blocks are confirmed to be applicable to the Kubuqi Desert, the Loess Plateau, and other devastated hilly areas in China where the annual precipitation is $400 \mathrm{~mm}$ or less (Obayashi et al., 2010; Saito et al., 2010; Yamadera, 2010).

In this test, a base soil was prepared by mixing surface soil, cow dung, and clay at a ratio of $18: 18: 2$, mixing a compound fertilizer $(\mathrm{N}: \mathrm{P}=15: 42)$ into the base soil at a rate of $2 \mathrm{~g}$ of fertilizer to $1 \mathrm{~L}$ (approx. $1 \mathrm{~kg}$ ) of the base soil,

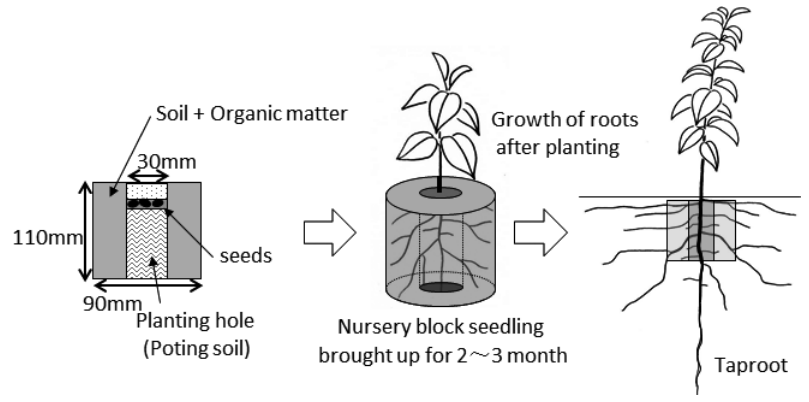

Fig. 4 Summary of nursery block seedling

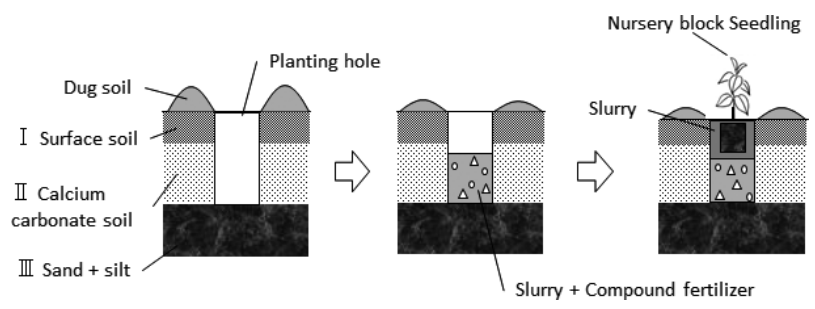

Fig. 5 Construction process of nursery block seedling

and then forming the mixture into nursery blocks using exclusive equipment. The nursery block seedlings were used after being planted in a plastic greenhouse beside the test site and grown for about three to four months.

\subsection{Planting Test of Eight Tree Species}

Figure 5 shows how the nursery block seedling was planted. First, planting holes $12 \mathrm{~cm}$ in diameter and $60 \mathrm{~cm}$ in depth were dug using an electric auger. Each hole was backfilled with a mixture of dug-out soil and $50 \mathrm{~g}$ of compound fertilizer $(\mathrm{N}: \mathrm{P}: \mathrm{K}=15: 15: 15)$ to a depth of $50 \mathrm{~cm}$, and then $3 \mathrm{~L}$ of water was poured into the hole. After the $3 \mathrm{~L}$ of water permeated into the soil, an additional $2 \mathrm{~L}$ of water was poured in, and then dug-out soil was added and agitated to form slurry. Then, a nursery block seedling was planted by inserting it into the slurry.

Eight tree species selected from those widely planted in northern China (Inner Mongolia Quality and Technical Supervision Bureau, 2003) were planted. The eight tree species adopted were Platycladus orientalis (L.) Franco, U. pumila, P. ansu, Prunus persica (L.) Batsch, Robinia pseudoacacia L., Acer truncatum Bunge, Fraxinus chinensis Roxb., and $S$. oblata. Forty-one (41) to 50 seedlings were planted in a row by tree species in the north-south direction. The number of seedlings of each tree species was 42 for $P$. orientalis, 45 for U. pumila, 130 for $P$. ansu, 44 for $P$. persica, 45 for $R$. pseudoacacia, 88 for A. truncatum, 131 for $F$. chinensis, and 45 for S. oblata; therefore, the total number of seedlings was 533. The interval between seedlings and that between rows were both $1 \mathrm{~m}$. Seedlings were planted in a zigzag pattern with those planted in the adjacent rows.

Seedlings were planted from August 3 to August 6, 2014. 
Two liters of water was fed to each seedling in April 2015, but after that, watering was not performed until October 7 , 2015.

\subsection{Survey items}

After the planting described above, the survival rate, tree height, and root shape were surveyed. Surveys were conducted on August 6, August 23, and October 4, 2014, and on July 23, August 15, August 20, and October 7, 2015. However, only the root shape was surveyed on August 19, 2015. However, goats invaded the test site during the observation period from August 15 to October 7 in 2015, and four species of trees suffered damage. The goats ate the tip portions such as terminal buds and side buds of four species, $U$. pumila, $P$. ansu, $P$. persica, and S. oblate, resulting in a decrease in the average tree height. On the other hand, $P$. orientalis was not damaged by goats.

The Mann-Whitney U test was performed for the average measurements of each survey item in order to check for significant differences. The significance level was less than $5 \%$ $(\mathrm{p}<0.05)$.

\section{Results}

Figure 6 shows the changes in the survival rate of the eight tree species. The survival rate as of October 7, 2015, which is approx. one year and two months after the planting, was highest at $98 \%$ for $U$. pumila, next highest at $84 \%$ for $S$. oblata, $52 \%$ for $P$. persica, $30 \%$ for $P$. ansu, and lowest at 12 $\%$ for $P$. orientalis. The survival rate was confirmed to have decreased for all the tree species after passing the winter, and all individuals of $R$. pseudoacacia, A. truncatum and $F$. chinensis had withered and died. On the other hand, no conspicuous decrease was observed in the survival rate in the summer season from July 23 to August 15, 2015.

Figure 7 shows the changes in the average tree height of the eight tree species. The changes in the average tree

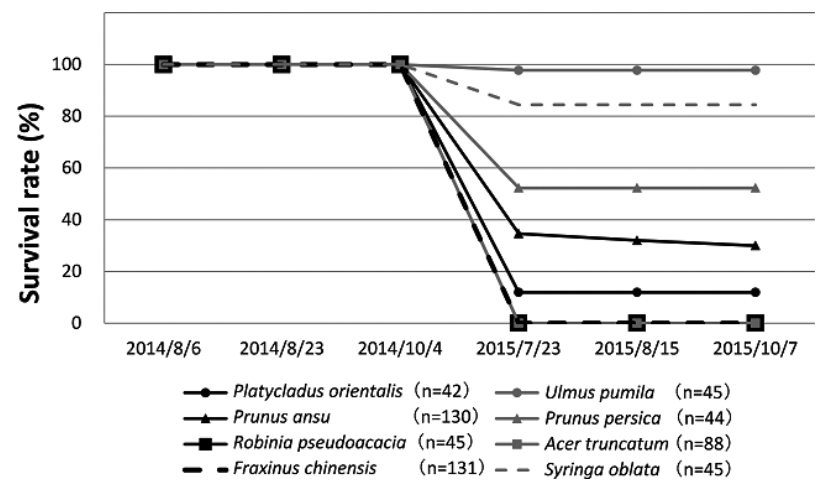

Fig. 6 Changes in woody plant survival rate from August 2014 to Octobe

(n) means the number of individuals at the planting date. height of the eight tree species are roughly classified into three types. The first is $U$. pumila, $P$. persica, and S. oblata in which the tree height did not decrease, but consistently increased (Group 1). The second is $P$. orientalis and $P$. ansu in which twigs had withered in the winter and the tree height had decreased (Group 2). The third is R. pseudoacacia, $A$. truncatum and $F$. chinensis in which all individuals were confirmed to have withered and died in 2015 (Group 3).

The average tree height of $P$. persica in Group 1 was $12.8 \pm 6.4 \mathrm{~cm}$ at the time of planting, and $13.4 \pm 6.4 \mathrm{~cm}$ as of October 4, i.e., two months after the planting, and therefore no significant increase was observed, but the average tree height as of July 23,2015 was $20.0 \pm 8.3 \mathrm{~cm}$, which shows a significant increase from the tree height as of October 4. After that, however, the average tree height did not increase significantly until August 15 . The average tree height decreased to $13.7 \pm 5.2 \mathrm{~cm}$ as of October 7, due to vermin damage by a goat. Also, U. pumila and S. oblata grew slightly just after the planting, but grew significantly after passing the winter, from October 4, 2014 to July 23, 2015. The increase in the average tree height approx. one year from the planting to October 7, 2015 was $10.8 \mathrm{~cm}$ for P. persica, 7.5 $\mathrm{cm}$ for $U$. pumila, and $4.1 \mathrm{~cm}$ for $S$. oblata.

The average tree height of $P$. orientalis in Group 2 was $8.7 \pm 2.0 \mathrm{~cm}$ at the time of planting, and $9.8 \pm 1.8 \mathrm{~cm}$ as of October 4 , i.e., two months after the planting, and therefore no significant increase was observed. Furthermore, twigs had withered during the winter, and the average tree height decreased to $3.4 \pm 1.9 \mathrm{~cm}$ by July 23,2015 , and did not increase significantly after that. The average tree height one year after the planting was $4.4 \pm 2.2 \mathrm{~cm}$, which is lower than $8.7 \pm$ $2.0 \mathrm{~cm}$, i.e., the tree height at the time of planting. The same applies to $P$. ansu.

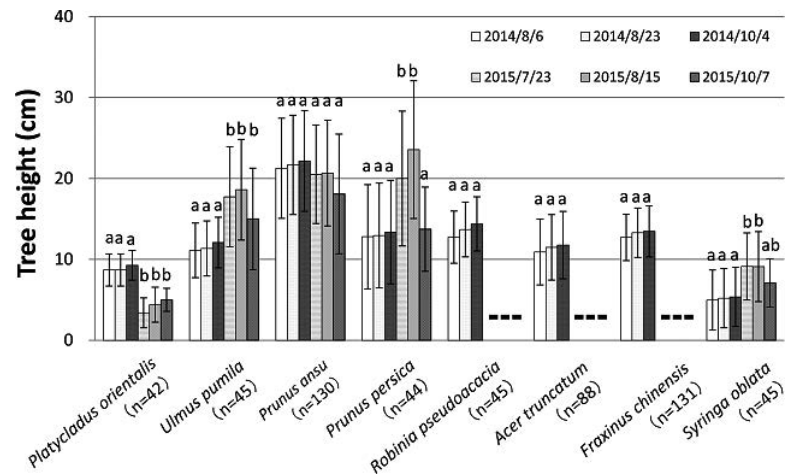

Fig. 7 Changes in woody plant tree height from August 2014 to August 2015 (mean \pm SD).

(n) means the number of individuals at the planting date. Planting date: August 3-6, 2014

- means that all individuals withered and died. Values with different letters are significantly different. 
The average tree height of $R$. pseudoacacia in Group 3 was $12.8 \pm 3.2 \mathrm{~cm}$ at the time of planting, and $14.4 \pm 3.4 \mathrm{~cm}$ as of October 4, i.e., two months after the planting, and therefore a tendency to increase was observed. However, all the individuals withered and died during the winter. The same applies to $A$. truncatum and $F$. chinensis.

Groups grow roots system was the same of the changes in the average tree height. Figure 8 shows photographs of the root systems of $U$. pumila, which had grown well (Group 1), $P$. ansu for which the average tree height had decreased during the winter (Group 2), and F. chinensis for which all the individuals had withered or died (Group 3). Both the taproots and lateral roots of $U$. pumila had grown, and the taproots had grown to a depth of $40 \mathrm{~cm}$. The roots of $P$. ansu had grown wide in the horizontal direction, but only to a depth of approx. $25 \mathrm{~cm}$ in the vertical direction. The roots of $F$. chinensis had not grown to the outside of the nursery blocks.

\section{Conclusion}

Planting eight tree species, this study confirmed that the survival rate was higher than $50 \%$, and the tree height had increased for U. pumila, P. persica and S. oblata. (Figs. 6 and 7). Regarding the root systems of $U$. pumila, for which the survival rate was high and the tree height had increased, the taproots had grown, and the lateral roots had grown wide diagonally downward. On the other hand, regarding P. ansu, rootage was partly confirmed and the root systems had grown to a depth of $25 \mathrm{~cm}$, but there were few roots and they had grown only in a narrow range. The roots of $F$. chinensis had not grown at all, but had withered and died (Fig. 8). In the preliminary soil profile investigation, there was no difference in the soil moisture by the depth. The soil moisture was constant at $7-10 \%$ throughout the depths from 10 to $70 \mathrm{~cm}$. Judging from these results, woody plants for which the root system had grown deep in the ground and

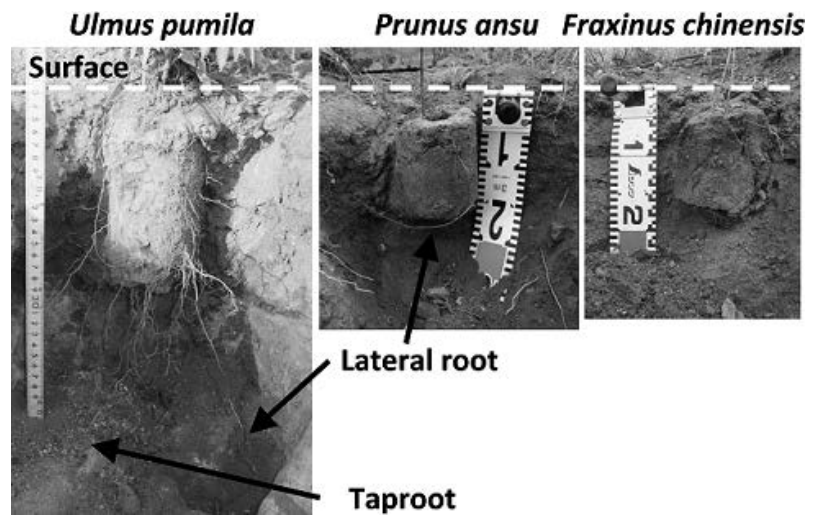

Fig. 8 Comparison of root structures, photographed on August 19, 2015, one year after the planting was able to absorb water from a wide range are considered to be able to grow even in white oasis soil.

In other words, this study confirmed that the most hindering factor for the introduction of woody plants into white oasis soil is its high hardness and poor air permeability. The growth comparison test in white oasis soil under limited watering conditions confirmed that $U$. pumila, P. persica and $S$. oblata are adaptable to white oasis soil. The introduction of woody plants into white oasis soil under limited watering conditions is considered possible by these tree species.

Acknowledgement: We express our gratitude to $\mathrm{Mr}$. Cheng, Mr. Wang, and other staff of Wing Luen Trade and Commerce Co., Ltd. in Xilingol League, who made arrangements for personnel and materials for the smooth conduct of this study, and to Mr. Koichi Oshimi from Mol, Inc., who came to China for the installation of the simplified tensiometer. We are grateful to $\mathrm{Mr}$. Bu who kindly supported us in our daily lives such as the preparation of meals.

Finally, we express our deepest appreciation to Former Vice President Tsuneaki Iwasaki, who made this research study possible, Mr. Shinichi Iwashita, Mr. Takashi Inagawa, and Mr. Toshio Sato from Oyo Corporation as well as Mr. Shiro Matsunami from Oyo International Corporation, who worked with us in China. This study complies with current laws of Japan and the People's Republic of China.

\section{References}

Araya, K., GUO, G., Ohomiya, K., Matsuda, J., Jia, H., Hashibagon, Li .W. (2003) Improvement of White Oasis Soil, Air Permeability of Soil and Aspect of Soil Failure. J. Env. Sci. Laboratory, Senshu Univ. 11: 137-142.

Dongwuzhumuqinqi government website (2004) Four preparing for deliberate spring afforestation.

http://www.dwq.gov.cn/_wxw_1/qnyw/201204/t 20120409_ 767421.html (2016.2.8 Inspected)

Dongwuzhumuqinqi government website (2016 Inspected) Outline of Dongwuzhumuqinqi, environment. http://www.dwq.gov.cn/xhqgk_1/zrdl/ (2016.2.8 Inspected)

Forestry Science and Technology Institute (1994) III Explanation for tree species. In: Forestry Science and Technology Institute. Learning of useful broadleaf tree, 3rd edn. Forestry Science and Technology Institute, Tokyo: pp. 31-492.

Furubayashi, D., Yamadera, Y., Yang, X., Miyazaki, T. (2003) The effect of nurse block for the growth of Robinia pseudoacacia. J. Jpn. Soc. Reveget. Tech. 29(1): 171-174.

Inner Mongolia Quality and Technical Supervision Bureau (2003) Official regulations of Afforestation technology in Inner Mongolia.

Nishikawa, M., Yamadera, Y., Miyazaki, T. (2004) Introduction of the vegetation into the land of dryness sand growing the tree plant using the Nurse Brock. J. Jpn. Soc. Reveget. Tech. 30(1): 328-331.

Obayashi, S., Saito, M., Sajiki, N., Yamadera, Y., Miyazaki, T., 
Yang, X. (2010) Research on method early-reforestation of a bare mountain in the Yellow River valley. J. Jpn. Soc. Reveget. Tech. 36(1): 171-174.

Qu Y. (2009) Chapter 11 Land and water resources and their utilization in desert areas. In: Wu $Z$ (ed.) SANDY DESERTS AND ITS CONTROL IN CHINA, 1st edn. Science Press, Beijing: pp. 378-433.

Saito, M., Gu, W., Shao, Q., Obayashi, S., Chen, S., Dai, Q. (2010) Experimental study on the application of nursery block technique for ecological restoration in Chinese Semiarid Area: a case study in hilly region of Xinghe in Inner Mongolia of China. J. Jpn. Soc. Reveget. Tech. 36(1): 167170 .

Wang, W. (2010) Hazards of sand storms and control. Inner
Mongolia University Press, Hohhot: pp. 9-69.

Wu, Z. (2009) Chapter 2 Distribution of arid areas and deserts in China. In: Wu Z (ed.) SANDY DESERTS AND ITS CONTROL IN CHINA, 1 st edn. Science Press, Beijing: pp. 17-24.

Yamadera, Y., Yang, X., Miyazaki, T. (2002) Study on the growth base for seeding technique (I) Purpose of the development of nurse block (PAPERS AND REPORTS OF THE 33RD SCIENTIFIC RESEARCH MEETING). J. Jpn. Soc. Reveget. Tech., 28(1): 197-200.

Yamadera, Y. (2010) Regeneration technology of natural environment. Japan Crushed Stone Association, Tokyo

Yamadera, Y. (2014) Importance of tap root for trees. Green Power 2014.6: pp. 4-5.

(Accepted: October 24, 2018) 